\author{
DOROTA PANKOWSKA \\ Uniwersytet Marii Curie-Skłodowskiej \\ w Lublinie
}

MARIOLA CHOMCZYŃSKA-RUBACHA

Uniwersytet Mikotaja Kopernika

$w$ Toruniu

\title{
FORMALNE PODSTAWY EDUKACJI A POLITYKA GENDER MAINSTREAMING
}

\begin{abstract}
Pankowska Dorota, Chomczyńska-Rubacha Mariola, Formalne podstawy edukacji a polityka gender mainstreaming [Formal Foundations of Education and the Gender Mainstreaming Policy]. Studia Edukacyjne nr 36, 2015, Poznań 2015, pp. 55-72. Adam Mickiewicz University Press. ISBN 978-83-232-2958-2. ISSN 1233-6688. DOI: 10.14746/se.2015.36.4
\end{abstract}

The article analyses and interprets the results of research about a hidden curriculum of gender roles in the act on the education system and the core curriculum of Polish school. The diagnosis is going to check what philosophy of education and what patterns of gender roles are hidden behind the texts of those documents. Is it an image of gender equality or inequality? The base our research is gender blind, neutral and sensitive education category. The results of our research are the starting point for constructing recommendations for educational policy.

Key words: policy of gender mainstreaming, the act of the education system, core curriculum of Polish school, gender equality, gender inequality

\section{Wprowadzenie}

Zestawienie kategorii płci i rodzaju z edukacją formalną kieruje uwage na rolę szkoły w reprodukowaniu versus zmianie ról i relacji rodzajowych w kierunku większej równości i sprawiedliwości rodzajowej. Kulturowo uwarunkowany system społecznych ról płciowych, w którym funkcjonuje szkoła czyni ją szczególnie podatną na transmisję tradycji, norm i wartości 
odnoszących się do pojęć kobiecości i męskości oraz relacji rodzajowych, dla których kluczowe znaczenie ma pojęcie władzy i jej nierównej dystrybucji. Szkoła, dzięki kontroli nad wiedzą i reprodukcją kulturową, może zatem podtrzymywać oparte na tradycji i męskiej dominacji relacje między płciami lub stać się rzeczniczką zmiany w kierunku równości i sprawiedliwości rodzajowej. Polska ma stosunkowo krótkie doświadczenia w zakresie wprowadzania polityki równościowej $\mathrm{w}$ edukacji. Ich początki sięgają wejścia Polski do Unii Europejskiej i podpisania/ratyfikowania dokumentów międzynarodowych (m.in. Konwencji o ochronie praw człowieka i podstawowych wolności, Konwencji praw dziecka, Konwencji w sprawie likwidacji wszelkich form dyskryminacji kobiet) zobowiązujących do przeciwdziałania wszelkim formom dyskryminacji: ze względu na płeć, pochodzenie, religię, sprawność fizyczną, wiek i orientację seksualną. Szczególnie zalecenia ostatniego dokumentu przewidują, że jego sygnatariusze podejmą środki, aby zmienić społeczne i kulturowe wzorce zachowań mężczyzn i kobiet $w$ celu likwidacji przesądów i zwyczajów oraz wszelkich innych praktyk, które opierają się na przekonaniu o niższości lub wyższości jednej z płci albo na stereotypach roli mężczyzn i kobiet.

Przedmiotem naszych badań czynimy edukację formalną, skupiając się głównie na filozofii edukacyjnej, dającej się odczytać z dwóch podstawowych dokumentów: Ustawy o systemie oświaty i podstaw programowych kształcenia ogólnego. Z konieczności poza naszym zainteresowaniem pozostawiamy takie aspekty edukacji formalnej, jak: ustrój szkolny, struktura szkolnictwa, zasady finansowania oświaty, infrastruktura i wyposażenie, kadra (wymagania, prawa, obowiązki), dostępność, system selekcji (w tym egzaminy zewnętrzne i znaczenie wewnątrzszkolnego oceniania), choć zdajemy sobie sprawę, że czekają one na rzetelną i pogłębioną analizę z punktu widzenia europejskiej strategii gender mainstreaming, zalecającej uwzględnianie perspektywy płci we wszystkich obszarach życia społecznego, z edukacją włącznie. Pomijamy również analizę procedury dopuszczania do użytku szkolnego podręczników i materiałów dydaktycznych, choć dotychczasowa praktyka pokazuje, że nie obejmuje ona monitoringu treści ze względu na eliminację wszelkich form dyskryminacji i stereotypizacji ze względu na płeć, ograniczając się jedynie do poprawności merytorycznej i metodycznej treści ${ }^{1}$.

Skupienie uwagi na analizie podstawowych dokumentów określających filozofię edukacji wynika ze szczególnej roli, jaką pełnią one w polskim zde-

${ }^{1}$ Na szczęście lukę tę z nawiązką wypełnia projekt badawczy: Gender w podręcznikach, którego wyniki wkrótce zostaną opublikowane. 
centralizowanym systemie oświatowym. Zarówno Ustawa o systemie oświaty, jak i podstawy programowe kształcenia ogólnego można traktować jako narzędzia kontroli władz oświatowych nad praktyką oświatową. Rola ta przypada szczególnie podstawie programowej, która wyznacza obowiązkowy i wspólny dla wszystkich uczniów i uczennic na danym etapie nauki kanon treści kształcenia składających się na wspólne doświadczenie edukacyjne. Wysoki poziom ogólności treści i efektów kształcenia pozwala na swobodę $\mathrm{w}$ konstruowaniu zindywidualizowanych wersji programów nauczania i podręczników, ale nawet $w$ takiej lapidarnej i skondensowanej formie stanowi manifestację intencji ideologicznych twórców podstaw programowych i Ustawy. Zdaniem Krzysztofa Konarzewskiego ${ }^{2}$, intencje te są dwojakiego rodzaju - polityczne i pedagogiczne. Intencje polityczne wyrażają wizję pożądanego ładu społecznego, wskazując na system wartości, które edukacja ma uobecniać i wspierać. I tak, w dokumentach tych obok chrześcijańskiego systemu wartości znajdujemy deklarację na temat pluralizmu światopoglądowego, religijnego, politycznego i obyczajowego, ideę rozwoju społeczeństwa obywatelskiego, ideę wspólnej Europy itp. Intencje pedagogiczne określają cele i zadania szkoły z punktu widzenia potrzeb jednostki i zbiorowości. Manifestują się one poprzez przekonania na temat formalnych ram edukacji, głównie jednak za pośrednictwem wyboru i selekcji materiału nauczania. Dominujące w programie typy wiedzy i czas przeznaczony na różne przedmioty i treści pośrednio informują, jaka wiedza jest wartościowa i w związku z tym zasługuje na szerszą reprezentację. Podstawy programowe oddają preferowane rozstrzygnięcia $\mathrm{w}$ tym zakresie i tym samym stanowią wskazówkę dla autorów oraz autorek programów i podręczników, jakie ich wybory zyskają akceptację decydentów.

Nas interesować będzie oczywiście zidentyfikowanie przekazów kulturowych i socjalizacyjnych związanych z płcią i rodzajem. Zabieg ten staje się możliwy, dzięki potraktowaniu tych dokumentów jako tekstów kultury ${ }^{3}$ i zastosowaniu do analizy treści kryterium gender mainstreaming. Od ich omówienia rozpoczniemy zatem naszą prezentację.

Część właściwa poświęcona jest analizie i interpretacji wyników badań nad przekazami dotyczącymi płci i rodzaju zawartych w kluczowych dokumentach, $\mathrm{tj}$. $\mathrm{w}$ ustawie o systemie oświaty i podstawach programowych. Liczymy na to, że posłużenie się instrumentarium analizy genderowej, szczególnie zaś wykorzystanie kategorii ślepej/neutralnej/wrażliwej rodzajowo edukacji pozwoli udzielić odpowiedzi na pytania:

2 K. Konarzewski, Reforma oświaty. Podstawa programowa $i$ warunki ksztatcenia, Warszawa 2004, s. 18.

${ }^{3}$ K. Rubacha, Metodologia badań nad edukacja, Warszawa 2008, s. 158. 
- czy kategoria płci/rodzaju jest obecna w dokumentach,

- jeśli tak, to czy sposób jej przedstawiania wyraża równość czy nierówność kobiet/mężczyzn oraz

- czy w zakresie wzorców kulturowych ról rodzajowych: utrwala tradycyjne wzorce, reprodukuje status quo, czy promuje zmiany społeczne w tym zakresie.

W zakończeniu, odwołując się do społecznych funkcji edukacji, zidentyfikujemy filozofię edukacji, jaka wyłania się z analizy celów i treści podstaw programowych oraz przedstawimy rekomendacje dla polityki oświatowej.

\section{Główne pojęcia i narzędzia analizy rodzajowej}

Potraktowanie Ustawy o systemie oświaty i podstaw programowych jako teksów kultury odwołuje się do paradygmatu interpretatywnego. Zakłada on, że tzw. wiedza szkolna nie stanowi obiektywnej reprezentacji stanu wiedzy ani stanu społeczeństwa, lecz rodzaj konstruktu społeczno-kulturowego. Uznanie tego faktu pozwala analizować wszelkie dokumenty jako źródła przekazów kulturowych i socjalizacyjnych. Daje zatem podstawy do rekonstrukcji wizji społecznego systemu ról płciowych, relacji rodzajowych oraz nierówności i różnic we władzy między nimi z perspektywy gender mainstreaming.

Gender mainstreaming w tłumaczeniu oznacza włączenie problematyki płci do głównego nurtu. Celem tej strategii jest wprowadzenie równości szans dla kobiet i mężczyzn we wszystkich obszarach życia społecznego, zarówno na etapie planowania, jak i realizacji działań. Zasada ta dotyczy wszelkich instytucji i organizacji, włączając w to także instytucje edukacyjne. Pojęcie to zadomowiło się w polskiej sferze publicznej wraz z przystąpieniem naszego kraju do Unii Europejskiej i wyznaczyło nowe standardy dla systemu oświatowego. Obowiązek wdrożenia polityki równościowej w edukacji wymaga zastosowania narzędzi analizy genderowej do różnych aspektów edukacji.

Analiza genderowa bada w systematyczny sposób relacje pomiędzy kobietami i mężczyznami i różnice w nierównościach i władzy między nimi. Prowadzenie tego typu analizy wymaga stawiania pytań w rodzaju: Co kto robi? Kto podejmuje decyzje? Co kto posiada i dlaczego? Celem tego rodzaju analizy jest promowanie równościowej i sprawiedliwej organizacji życia społecznego. Analiza ta wykorzystuje takie pojęcia, jak: płeć i rodzaj, role i relacje rodzajowe, pryzmaty rodzaju, tradycyjny system ról płciowych, stereotypy i uprzedzenia płciowe, dyskryminacja i seksizm, równość i spra- 
wiedliwość rodzajowa. Kluczowe znaczenie ma tu zwłaszcza rozróżnienie pojęcia rodzaju (ang. gender) od pojęcia płci (ang. sex), które służy podkreśleniu społeczno-kulturowej, a nie biologicznej genezy różnic w zakresie cech osobowości, zainteresowań, typów aktywności i podejmowanych przez kobiety i mężczyzn ról społecznych. Pojęcie role rodzajowe służy do opisu zmiennych w czasie zakresów działania i wzorców zachowań wyznaczanych kobietom i mężczyznom, zaś pojęcie relacje rodzajowe wskazuje na społeczne interakcje pomiędzy kobietami i mężczyznami w sferze prywatnej i publicznej z uwypukleniem relacji władzy i zależności między płciami. Użyteczne $\mathrm{w}$ analizie genderowej jest pojęcie pryzmaty rodzaju. Służy ono do opisu społeczno-kulturowej genezy ukrytych założeń dotyczących płci i rodzaju. Sandra Bem ${ }^{4}$ wymienia trzy pryzmaty rodzaju: androcentryzm (stawianie w centrum uwagi pierwiastka i wartości męskich), polaryzacje rodzajów (przydzielanie kobietom i mężczyznom innych zadań i postrzeganie ich jako ludzi o odmiennych typach osobowości), esencjalizm biologiczny (uzasadnianie różnic między mężczyznami i kobietami biologicznym wyposażeniem człowieka). Na tak rozumianych pryzmatach rodzaju jest zbudowany tradycyjny system ról płciowych: podział aktywności w zależności od płci (polaryzacja), przypisywanie cech psychicznych zgodnie z płcią biologiczną (esencjalizm biologiczny) oraz przyznawanie wyższej wartości temu, co męskie (androcentryzm) 5 .

Kolejna grupa pojęć wykorzystywanych $\mathrm{w}$ analizie genderowej to: stereotypy i uprzedzenia płciowe, dyskryminacja i seksizm. Pojęcia te opisują praktykę gorszego traktowania ludzi ze względu na przynależność grupową (m.in. płeć), będącą skutkiem uproszczonych przekonań i sądów. Ostatnia grupa pojęć to równość i sprawiedliwość rodzajowa. I tak, równość odwołuje się do pojęcia równych praw, które umożliwiają równy status mężczyzn i kobiet bez ignorowania różnic biologicznych, zaś sprawiedliwość rodzajowa odnosi się do sprawiedliwego i równego dostępu do korzystania z tych praw. Dla edukacji oznacza to na przykład taki dobór treści nauczania, który nie faworyzuje żadnej grupy płciowej.

Z punktu widzeniu celu naszych badań - diagnozy i analizy przekazów socjalizacyjnych z perspektywy równego i sprawiedliwego traktowania płci $\mathrm{w}$ podstawowych dokumentach oświatowych - użyteczne jest posłużenie się jeszcze jedną kategorią: edukacji ślepej (niewrażliwej) na rodzaj, neutralnej wobec rodzaju oraz wrażliwej na rodzaj6. Kategoria ta pozwala w bardziej syn-

\footnotetext{
4 S. Bem, Męskość, kobiecość. O różnicach wynikających z ptci, Gdańsk 2000, s. 15-16.

${ }^{5}$ D. Pankowska, Wychowanie a role ptciowe, Gdańsk 2005, s. 19.

${ }^{6}$ F. Leach, Practising Gender Analysis in Education, Oxford 2003, s. 22.
} 
tetyczny sposób odnieść powyższe pojęcia do obszaru edukacji jako przedmiotu badań.

Edukacja ślepa na rodzaj (nieświadoma rodzaju). Ten typ edukacji cechuje brak świadomości na temat rodzajowej natury społeczeństwa. Brak refleksji, że rodzaj jest podstawową determinantą wyborów życiowych i relacji władzy sprawia, że różne parametry systemu oświatowego (organizacja kształcenia, konstrukcja programów, treści podręczników, nauczyciele) pozostają poza kontrolą. A to oznacza, że mogą być w sposób nieuświadomiony stronnicze i faworyzować pewne grupy uczniów, a deprecjonować inne. Ze względu na androcentryczne i patriarchalne aspekty naszej kultury, edukacja ślepa na płeć jest często nośnikiem uprzedzeń rodzajowych. Nieświadome kwestii rodzaju praktyki edukacyjne często uprzywilejowują męskie potrzeby, zainteresowania i priorytety. Można wskazać wiele przykładów takiej „rodzajowej ślepoty” obecnych w podręcznikowych tekstach, ilustracjach i języku faworyzującym rodzaj męski. Tego rodzaju ślepota prowadzi do nierówności dziewcząt i chłopców w zakresie dostępu do edukacji, uczestnictwa w procesie edukacyjnym i sukcesu edukacyjnego.

Edukacja neutralna rodzajowo. Podejście to oznacza, że programy, plany i materiały dydaktyczne akceptują istnienie rodzajowego podziału szans i możliwości, i nie stawiają sobie za cel zmiany relacji rodzajowych. Akceptując obecność różnic w społeczeństwie i działając w jego kulturowych ramach, starają się jednak pozostawać w zgodzie z rzeczywistymi, a nie życzeniowymi wizjami ról i relacji rodzajowych. Służy temu troska o zgodność podręcznikowych opisów świata i materiałów programowych z rzeczywistością, a nie ze stereotypami. Skutek jest taki, że podręczniki i materiały są raczej neutralne rodzajowo niż nieświadome rodzaju.

Edukacja wrażliwa na rodzaj. Promuje ona aktywnie równość i sprawiedliwość rodzajową. Perspektywa ta identyfikuje relacje rodzajowe jako problem i jest zorientowana na podejmowanie krótko- i długofalowych działań służących obalaniu stereotypów i przedstawianiu mężczyzn, kobiet i relacji między nimi w sposób wolny od uprzedzeń i dyskryminacji. Podejście wrażliwe na rodzaj stawia sobie za cel kreowanie środowiska edukacyjnego jako przestrzeni wolnej od pryzmatów rodzaju, stereotypów i seksizmu. Dlatego w materiałach dydaktycznych wykorzystuje takie strategie, jak: zwiększenie częstotliwości przedstawiania mężczyzn w sferze rodzin- 
nej, zwiększenie liczby modeli kobiecych w dziedzinie nauki, techniki, w rolach profesjonalistek i przywódczyń, unikanie stronniczego rodzajowo języka itp.

Omówione pokrótce instrumentarium analizy genderowej i strategie promowania edukacji wolnej od dyskryminacji są dobrze zadomowione w krajach Unii Europejskiej. Zobaczmy zatem, czy ich obecność daje się zidentyfikować w podstawowych dokumentach wyznaczających funkcjonowanie polskiego sytemu oświatowego: Ustawie o systemie oświaty i podstawach programowych kształcenia ogólnego.

\section{Wyniki analizy \\ Ustawy z dnia 7 września 1991 r. o systemie oświaty wraz z późniejszymi zmianami ${ }^{7}$}

Ustawa ta jest dokumentem, który zapewnia przede wszystkim prawne i finansowe podstawy powoływania oraz prowadzenia szkół publicznych i niepublicznych (i innych placówek w systemie oświaty związanych z edukacją przedszkolną i doskonaleniem nauczycieli), zasady rekrutacji i nadawania kwalifikacji (egzaminy, świadectwa i dyplomy), przepisy dotyczące zarządzania placówkami i sprawowaniem nad nimi nadzoru pedagogicznego. W całym tekście Ustawy nie ma żadnego odniesienia do płci, choć język dokumentu - podobnie jak przeważająca większość dokumentów prawnych w Polsce - posługuje się rodzajem męskim jako uniwersalnym (uczeń/ uczniowie, nauczyciel/e, dyrektor, kurator, minister itp.). Nawet kiedy mowa o możliwości i warunkach wprowadzenia w szkole jednolitego stroju (art. 64a), nie wspomina się o jego zróżnicowaniu ze względu na płeć uczniów/uczennic.

Trudno też uznać, że Ustawa wyraża spójną wizję filozofii edukacyjnej państwa, choć we wstępie oraz w art. 1 są określone podstawowe zasady oraz pewne zakładane efekty kształcenia i wychowania. Nie sformułowano wprost zasady równości (w tym równości ze względu na płeć), jednak wynika ona implicite z ogólniejszych podstaw prawnych, do których odwołuje się Ustawa: Konstytucji Rzeczpospolitej Polskiej, Powszechnej Deklaracji Praw

7 DzU 1991, nr 95, poz. 425, tekst ujednolicony D19910425Lj.pdf w: http://isap.sejm.gov. pl/DetailsServlet?id=WDU19910950425, [dostęp: 20.04.2015]. 
Człowieka, Międzynarodowego Paktu Praw Obywatelskich i Politycznych oraz Konwencji o Prawach dziecka. Szczególnie podkreślane jest prawo każdego obywatela ( $w$ domyśle: i obywatelki) do kształcenia oraz prawo dzieci i młodzieży do opieki i wychowania (art. 1.1). Implicite, w poszczególnych przepisach zawarta jest troska o zwiększenie/wyrównanie szans rozwojowych niektórych grup uczniów, ale nie odnosi się to do ich płci (chodzi o osoby z niepełnosprawnością, trudnościami w uczeniu się, niedostosowane społecznie, znajdujące się $\mathrm{w}$ trudnej sytuacji materialnej, należące do mniejszości narodowych, etnicznych, regionalnych, pochodzące z innych krajów).

Nie można na podstawie analizowanego dokumentu stwierdzić, jakie wzorce kobiecości i męskości szkoła promuje: tradycyjne, reprodukujące status quo, czy ukierunkowane na zmianę, skoro kategoria płci/rodzaju nie występuje w dokumencie w żadnym kontekście. Jednak na podstawie analizy explicite określonych zasad i celów można dojść do wniosku, że ich sens oraz sposób formułowania mają dość konserwatywny i adaptacyjny charakter, o niewielkim potencjale emancypacyjnym. Warto przytoczyć je w całości: Nauczanie i wychowanie - respektując chrześcijański system wartości - za podstawe przyjmuje uniwersalne zasady etyki. Ksztatcenie $i$ wychowanie stuży rozwijaniu u młodzieży poczucia odpowiedzialności, miłości ojczyzny oraz poszanowania dla polskiego dziedzictwa kulturowego, przy jednoczesnym otwarciu się na wartości kultur Europy i świata. Szkoła winna zapewnić każdemu uczniowi warunki niezbędne do jego rozwoju, przygotować go do wypetniania obowiazków rodzinnych i obywatelskich w oparciu o zasady solidarności, demokracji, tolerancji, sprawiedliwości i wolności (s. 1). Być może specyfika używanych sformułowań, a przede wszystkim niespójność aksjologiczna tekstu powoduje, że wartości o pewnym potencjale emancypacyjnym, jak indywidualny rozwój, demokracja, tolerancja, sprawiedliwość, wolność nie nadają tonu całości wypowiedzi. Warto jednak uwzględnić, że o ile szczegółowe rozwiązania i przepisy Ustawy były w ciągu prawie ćwierćwiecza od jej powstania wielokrotnie zmieniane, to cytowana preambuła - nie, a tworzona była przecież w zupełnie innych warunkach społeczno-politycznych. Można zatem przypuszczać, że więcej będzie można wywnioskować z analizy podstaw programowych kształcenia ogólnego, które są co kilka lat aktualizowane, a jednocześnie muszą być $\mathrm{w}$ całości uwzględniane $\mathrm{w}$ realizowanych przez placówki przedszkolne i szkoły programach edukacyjnych i dopuszczonych do użytku szkolnego podręcznikach (art. 22a, 22ao). 


\section{Wyniki analizy \\ Podstawy programowej wychowania przedszkolnego i kształcenia ogólnego dla poszczególnych etapów edukacji szkolnej ${ }^{8}$}

1. Analiza ogólnych celów i wymagań edukacji szkolnej zawartych w podstawach programowych wskazuje, że edukacja przedszkolna i szkolna jest „niewrażliwa na płeć”, zachowując neutralność zarówno w odniesieniu do efektów, jak i treści kształcenia. Nie ma jakiegokolwiek zróżnicowania w tym zakresie w odniesieniu do płci uczniów: i dziewczęta i chłopcy powinni spełnić te same wymagania i przyswoić ten sam zakres treści. Nawet w przypadku wychowania fizycznego nie określa się innych standardów sprawności fizycznej chłopców i dziewcząt na żadnym poziomie edukacyjnym, nie różnicuje się treści, a w zaleceniach do realizacji nie wskazuje, aby zajęcia były prowadzone $w$ jednopłciowych grupach (podobnie jak w przypadku zajęć technicznych i wychowania do życia w rodzinie). Jedynym odniesieniem do płci w programie wychowania fizycznego jest cel z zakresu edukacji zdrowotnej: omawia zalecenia dotyczące aktywności fizycznej w zależności od płci, okresu życia i rodzaju pracy zawodowej (IV etap, s. 262).

2. W wymaganiach i treściach kształcenia kategoria płci pojawia się przede wszystkim w kontekście demograficznym - struktury ludności według płci (geografia, III etap, s. 177) oraz:

- biologicznego zróżnicowania organizmów w odniesieniu do rozmnażania płciowego i dziedziczenia (biologia - III etap, s. 194);

- anatomii i fizjologii człowieka - układu rozrodczego i dokrewnego (przyroda - II etap, s. 38; wychowanie do życia w rodzinie - II etap, s. 50; biologia - III etap, s. 193; biologia IV etap - zakres rozszerzony, s. 208);

- ciąży i porodu (wychowanie do życia w rodzinie - II etap, s. 50; III etap, s. 266; biologia - III etap, s. 193; IV etap, s. 269; biologia - IV etap - zakres rozszerzony, s. 208);

8 Podstawa programowa wychowania przedszkolnego dla przedszkoli i innych form wychowania przedszkolnego. Załącznik nr 1; Podstawa programowa kształcenia ogólnego dla szkół podstawowych. Załącznik nr 2 do Rozporządzenia Ministra Edukacji Narodowej z 30 maja $2014 \mathrm{r}$. zmieniające rozporządzenie $\mathrm{w}$ sprawie podstawy programowej wychowania przedszkolnego oraz kształcenia ogólnego w poszczególnych typach szkół; DzU z 18 czerwca 2014 r., poz. 803 oraz Podstawa programowa kształcenia ogólnego dla gimnazjów i szkół ponadgimnazjalnych, których ukończenie umożliwia uzyskanie świadectwa dojrzałości po zdaniu egzaminu maturalnego. Załącznik nr 4 do Rozporządzenia Ministra Edukacji Narodowej z 27 sierpnia 2012 r. w sprawie podstawy programowej wychowania przedszkolnego oraz kształcenia ogólnego w poszczególnych typach szkół; DzU z 30 sierpnia 2012 r., poz. 977. 
- okresu dojrzewania płciowego (przyroda - II etap, s. 38; wychowanie do życia w rodzinie - II etap, s. 50; biologia - III etap, s. 193; biologia IV etap - zakres rozszerzony, s. 208).

Jedynie w ramach przedmiotu „wychowanie do życia w rodzinie” mowa jest o identyfikacji z płcią (II etap - s. 50, III etap - s. 323), akceptacji własnej płciowości (wychowanie do życia w rodzinie - III etap, s. 268) czy tożsamości płciowej, i to w kontekście problemów z jej osiąganiem - przede wszystkim $\mathrm{w}$ wymiarze biologicznym i psychoseksualnym (hasło programowe: Kształtowanie i akceptacja tożsamości płciowej. Możliwości pomocy w pokonywaniu trudności zwiazanych z tożsamościa płciowa - etap III, s. 269; Trudności w osiaganiu tożsamości płciowej, możliwości pomocy - etap IV, s. 270). I niemal wyłącznie w ramach tego przedmiotu można znaleźć odniesienia do płci społeczno-kulturowej (bez używania tego pojęcia) w bardzo ograniczonym zakresie:

- rozumienie kobiecości i męskości w odniesieniu do tożsamości płciowej i rozwoju seksualnego (hasła: Podstawowe informacje o rozwoju seksualnym człowieka: tożsamość ptciowa: męskość i kobiecość; Wartości zwiazane z seksualnościq człowieka: męskość, kobiecość, miłość, matżeństwo, rodzicielstwo - etap III, s. 269; Wartości i pojęcia związane z płciowościa człowieka: męskość, kobiecość, miłość, rodzina, rodzicielstwo - etap IV, s. 270);

- różnice między dziewczętami i chłopcami/kobietami i mężczyznami (hasła programowe: Różnice i podobieństwa między chłopcami i dziewczętami - II etap, s 50; Różnice w rozwoju psychoseksualnym dziewcząt $i$ chłopców; postawy i wzajemne oczekiwania - etap III, s. 269; Komplementarność płci - wzajemne dopetnianie się ptci w sferach fizycznej, psychicznej, emocjonalnej i społecznej. Rozumienie, akceptacja i szacunek dla osób płci odmiennej - IV etap, s. 270);

- odniesienie do ról rodzinnych (hasło: Macierzyństwo i ojcostwo - II etap, s. 50; Płodność wspólna sprawa kobiety i mężczyzny - etap III, s. 269; Pogłębianie wiedzy związanej z funkcjami rodziny, miłościa, przyjaźnia, petnieniem ról małżeńskich $i$ rodzicielskich - etap IV, s. 269; Role kobiet i mężczyzn a panujace stereotypy; Macierzyństwo i ojcostwo. Przygotowanie do ról rodzicielskich; Prawa i obowiązki matżonków i rodziców, prawa dziecka - IV etap, s. 270-271).

Incydentalnie $\mathrm{w}$ treściach innych przedmiotów pojawia się nawiązanie do ról społecznych (choć niekoniecznie ze wskazaniem na role kobiet i mężczyzn) bądź relacji między płciami:

- historia i społeczeństwo na II etapie edukacyjnym (cel: wyjaśnia znaczenie rodziny w życiu oraz wskazuje przykłady praw i obowiązków przysługujących poszczególnym członkom rodziny - s. 30)

- historia i społeczeństwo jako przedmiot uzupełniający na IV etapie edukacyjnym, w temacie 3: „Kobieta i mężczyzna, rodzina” (analiza na wy- 
branych przykładach roli kobiety i mężczyzny oraz modele rodziny w Biblii i starożytnej Grecji i Rzymie, s. 291);

- wiedza o społeczeństwie na III etapie (hasło: rozpoznaje role społeczne, w których występuje oraz zwiazane z nimi oczekiwania - s. 150);

- wiedza o społeczeństwie - IV etap - poziom rozszerzony (prawa i obowiązki małżonków w kontekście matżeństwa jako instytucji prawnej - s. 168)

- podstawy przedsiębiorczości - IV etap (hasło: charakteryzuje swoje role spoteczne i typowe dla nich zachowania - s. 172);

- wychowanie fizyczne - III etap (hasło: omawia znaczenie dla zdrowia dobrych relacji $z$ innymi ludźmi, w tym z rodzicami oraz rówieśnikami tej samej i odmiennej ptci-s. 262).

Jak widać z powyższego zestawienia, podstawa programowa nie charakteryzuje ról małżeńskich czy rodzicielskich $\mathrm{w}$ zależności od płci, jak również różnic $\mathrm{w}$ rozwoju psychoseksualnym dziewcząt i chłopców, zachowując pełną neutralność (niewrażliwość) rodzajową, choć wskazuje na ich istnienie.

3. Neutralność rodzajowa jest jednak pozorna ze względu na androcentryczny język. W każdym wypadku, gdy wymieniane są czy to podmioty edukacji (nauczyciel/e, uczeń/uczniowie), czy inne osoby (np. bohater literacki, przedstawiciele zawodów/edukacja społeczna, I etap, s. 14/czy grup społecznych) - stosowany jest rodzaj męski jako uniwersalny (z pewnym wyjątkiem podstaw programowych wychowania przedszkolnego i I etapu edukacyjnego, gdzie zamiennie ze słowem "uczeń/uczniowie”, używa się "dziecko/dzieci” w rodzaju nijakim). Tego rodzaju praktyki językowe prowadzą $w$ efekcie do symbolicznego wykluczenia kobiet/dziewcząt jako nadawczyń i adresatek przekazów. „Niewidzialność/nieobecność” uczennic manifestowana poprzez unikanie rodzaju żeńskiego okazuje się (zapewne nieuświadamianą) strategią pomniejszania i marginalizowania znaczenia kobiet/dziewcząt.

4. Dominacja androcentrycznej perspektywy manifestuje się ponadto poprzez przewagę $\mathrm{w}$ niektórych zakresach treści kształcenia kojarzonych z kulturowo zdefiniowaną męskością. Tak się dzieje w przypadku zajęć technicznych, które nastawione są:

- na II etapie edukacyjnym na: rozpoznawanie i opis działania elementów środowiska technicznego; planowanie $i$ realizacje praktycznych działań technicznych; sprawne $i$ bezpieczne postugiwanie się sprzętem technicznym, w związku z tym uczniowie (i w domyśle: uczennice) mają m.in. wykonywać odręczne szkice techniczne, konstruować modele, korzystając z gotowych zestawów do montażu elektronicznego i mechanicznego, posługiwać się podstawowymi narzędziami stosowanymi do obróbki ręcznej (piłowania, cięcia, szlifowania, wiercenia) (s. 47); 
- na III etapie edukacyjnym (jako przedmiot uzupełniający/fakultatywny) na: rozumienie zasad działania urzadzeń technicznych, rozwiązywanie problemów technicznych $i$ konstrukcyjnych, postugiwanie się narzędziami i przyrządami (s. 310), a jako przykład podano zajęcia modelarskie (s. 311).

Nie negując przydatności wiedzy i umiejętności technicznych dla każdego, bez względu na płeć, trudno nie zauważyć, że w programie nie ma żadnych umiejętności praktycznych wiązanych z kulturowo zdefiniowanymi rolami kobiecymi (gotowanie, szycie, sprzątanie i inne prace domowe). Co prawda $\mathrm{w}$ "Zalecanych warunkach i sposobach realizacji” zamieszczono uwagę, że na III etapie edukacyjnym: Rodzaj zajęć oraz realizowany program powinny być dostosowane do zainteresowań uczniów, a wśród przykładów rodzajów zajęć wskazano również krawiectwo i rękodzieło regionalne, a w jego ramach hafciarstwo (s. 326), jednak tego typu zajęcia niewiele mają wspólnego $\mathrm{z}$ celami i treściami przedmiotu.

5. Androcentryczną perspektywę wzmacnia również proporcja męskich i żeńskich postaci ważnych dla historii i kultury, np.:

- na II etapie edukacyjnym w ramach przedmiotu „historia i społeczeństwo" spośród postaci historycznych imiennie wymieniono 22 mężczyzn i tylko jedną kobietę - królową Jadwigę (s. 32-34), a na 8 osób zasłużonych dla kultury polskiej - dwie kobiety: Marię Skłodowską-Curie i Helenę Modrzejewską (a wśród bohaterów zbiorowych, jak mnisi, chłopi, rycerze, paziowie, czy przedstawicieli grup, np. mieszczanin, szlachcic - w ogóle nie ma żeńskich przedstawicielek);

- w treściach przedmiotu "historia” na III etapie edukacyjnym wymieniono 26 postaci męskich i żadnej kobiety (s. 128-134), podobnie brak jakiejkolwiek kobiety na IV etapie - w zakresie podstawowym (s. 135-138) i rozszerzonym (s. 138-149);

- brak postaci kobiecych, mimo że imiennie występują mężczyźni, również $\mathrm{w}$ podstawach programowych filozofii (IV etap, s. 121-127) i historii muzyki (IV etap, s. 113-116), a w treściach trzech wątków tematycznych poświęconych nauce i odkryciom $\mathrm{w}$ ramach przedmiotu uzupełniającego "przyroda" na IV etapie edukacyjnym (s. 297-298) na 40 wymienionych mężczyzn kobiety reprezentuje tylko Maria Skłodowska-Curie;

- w treściach programowych języka polskiego na III etapie wśród wymienionych 34 autorów jest 7 kobiet (s. 82), na IV etapie w zakresie podstawowym wśród 60 autorów/autorek tekstów kultury proponowanych do wyboru jest 6 kobiet, podobnie na IV etapie w zakresie rozszerzonym wśród ogólnej liczby 64 również znalazło się jedynie 6 kobiet (s. 87-88); z kolei w zestawie lektur obowiązkowych i do wyboru na II etapie edukacyjnym zdecydowanie przeważają książki (niezależnie od płci autora 
/13//autorki /8/), w których głównymi i aktywnie działającymi bohaterami są chłopcy (s. 24).

Opisana wyżej nierównowaga płci jest oczywiście z jednej strony uzasadniona historycznie i wynika z małego udziału kobiet w życiu publicznym i braku dostępu do wyższej edukacji przez większą część dziejów ludzkości, z drugiej - z założeń doboru treści w programach edukacyjnych, koncentrujących się na najwybitniejszych (i najbardziej znanych) przywódcach politycznych czy twórcach nauki i kultury. Widoczny jednak brak troski o zachowanie właściwych proporcji w prezentowaniu wkładu kobiet w rozwój kultury i nauki prowadzić może znowu do deprecjonowania ich wartości i znaczenia w życiu społecznym, naukowym itp.

6. Marginalizowanie kobiecego doświadczenia i sytuacji społecznokulturowej kobiet odbywa się również przez „odrywanie” od płci tego, co jest $\mathrm{z}$ nią ściśle związane, jak np.:

- bezosobowe przedstawianie - jako abstrakcyjnych i "ogólnoludzkich” procesów biologicznych - ciąży, porodu, rozwoju płodowego, naturalnego karmienia (wychowanie do życia w rodzinie: II etap, s. 57; IV etap, s. 271; przyroda II etap, s. 46; biologia, III etap, s. 193; IV etap, zakres rozszerzony, s. 208);

- pomijanie perspektywy rodzaju $\mathrm{w}$ analizowaniu kulturowych uwarunkowań postaw wobec urody i pielęgnacji ciała (przedmiot uzupełniający „przyroda”, IV etap, s. 309);

- odnoszenie hasła "gospodarstwo domowe" jedynie do występujących w nim urządzeń technicznych (zajęcia techniczne, I etap, s. 16, II etap, s. 55) bądź ekonomicznych podstaw jego funkcjonowania (wiedza o społeczeństwie, III etap, s. 155).

7. Analiza zawartości treści kształcenia przedmiotów społecznych i humanistycznych prowadzi do konstatacji, iż nie promują one w żaden sposób zmian społecznych, jakie już się dokonały i wciąż dokonują w systemie ról rodzajowych. Wydaje się, że w ramach takich przedmiotów jak historia, wiedza o kulturze czy język polski, zwłaszcza na III i IV etapie edukacyjnym, które odnoszą się w dużej mierze do okresu XIX i XX wieku, można by znaleźć więcej kobiecych postaci mających ważny dorobek zarówno w zakresie działalności politycznej i społecznej, jak też w dziedzinie szeroko pojętej kultury. Uczniowie i uczennice - zgodnie z programem - mają niewielkie szanse, aby dowiedzieć się o drodze kobiet do emancypacji i skutkach zmiany społecznej roli kobiet. $\mathrm{W}$ programie całej edukacji - od przedszkola do matury - są na ten temat trzy wzmianki, przy czym wszystkie na IV etapie edukacyjnym $\mathrm{w}$ podstawach programowych: 
- wiedzy o społeczeństwie w zakresie podstawowym w haśle dotyczącym praw człowieka uczeń/uczennica znajduje informacje o naruszaniu praw człowieka w wybranej dziedzinie (np. prawa kobiet, prawa dziecka, wolność wyznania, prawo do edukacji, prawa humanitarne) (s. 159) i w zakresie rozszerzonym: charakteryzuje wybrany ruch społeczny, np.: Solidarność, ruch niepodległościowy non-violence Mahatmy Gandhiego, ruch praw obywatelskich Martina L. Kinga, ruch na rzecz ochrony środowiska naturalnego, ruch emancypacji kobiet (s. 161);

- przedmiotu uzupełniającego "historia i społeczeństwo”, w jednym z tematów do wyboru „Kobieta i mężczyzna, rodzina” w haśle: wyjaśnia przemiany życia społecznego sprzyjajace emancypacji kobiet i przejawy tego procesu (s. 291).

Należy zwrócić uwagę, że z tematem emancypacji kobiet uczeń/uczennica może się spotkać, ale nie musi - zależy, czy w ramach wiedzy o społeczeństwie - w zakresie podstawowym - wybierze prawa kobiet jako przykład naruszania praw człowieka, czy - na poziomie rozszerzonym zainteresuje się ruchem emancypacji kobiet, a nie innym, wreszcie - czy będzie realizować przedmiot uzupełniający "historia i społeczeństwo" przeznaczony dla klas matematyczno-przyrodniczych oraz czy nauczyciel/ka spośród propozycji bloków tematycznych zdecyduje się realizować wątek „Kobieta i mężczyzna, rodzina”. W tym ostatnim przypadku interesujące jest również ujęcie problematyki emancypacji kobiet jako procesu, który "sam się dzieje" w wyniku sprzyjających warunków, a nie jako rezultat trwającej dziesiątki lat walki kobiet o swoje prawa i miejsce w społeczeństwie. Czy zatem szkolna edukacja nie daje szansy na zdobycie wiedzy o płci społeczno-kulturowej i przemianach społecznych w tym zakresie?

8. Przynajmniej teoretycznie można założyć, że choć szkoła w podstawach programowych zupełnie ignoruje gender mainstreaming, jako zasadę uwzględniania perspektywy rodzaju $\mathrm{w}$ różnych aspektach życia społecznego, nie zamyka całkiem takich możliwości. W podstawach programowych można znaleźć wiele sformułowań, które potencjalnie dają takie szanse, np. gdy uczeń/uczennica:

- opisuje etapy rozwoju demograficznego ludności na przykładach wybranych państw świata (geografia, IV etap, zakres rozszerzony, s. 186);

- wykazuje różnice $w$ strukturze zatrudnienia ludności w Polsce $i$ we własnym regionie (geografia, III etap, s. 177; także geografia, IV etap, zakres rozszerzony, s. 181) czy wyjaśnia znaczenie pracy człowieka i dostrzega jej społeczny podział (historia i społeczeństwo, II etap, s. 39);

- charakteryzuje zróżnicowanie religijne ludności świata i ocenia wptyw religii na postawy spoteczne i gospodarke (geografia, IV etap, zakres rozszerzony, s. 186); 
- wyjaśnia znaczenie kultury $i$ tradycji regionalnych w procesie różnicowania się regionów pod względem rozwoju społecznego i gospodarczego (geografia, IV etap, zakres podstawowy, s. 180);

- analizuje specyfikę kulturową Indii, regionów Bliskiego Wschodu, Ameryki Północnej i Południowej (geografia, III etap, s. 179);

- poznaje istotę demokracji, prawa człowieka oraz przypadki ich naruszania, a także przykłady, przyczyny i konsekwencje nierówności społecznych (wiedza o społeczeństwie, III etap, s. 150, 152; IV etap, zakres rozszerzony, s. 169, 161; etyka, IV etap, s. 324); ma ukształtować postawę wrażliwości społecznej na niesprawiedliwość i dyskryminację oraz postawę tolerancji (edukacja społeczna, I etap, s. 14; historia i społeczeństwo, II etap, s. 64; etyka, IV etap, s. 324);

- analizuje różne modele rodziny i ich przemiany (wiedza o społeczeństwie, IV etap, zakres rozszerzony, s. 160; przedmiot uzupełniający historia i społeczeństwo, blok tematyczny 3, IV etap, s. 291);

- zdobywa wiedzę i dokonuje refleksji dotyczącej socjalizacji, kontroli społecznej oraz mechanizmów powstawania stygmatyzacji społecznej (wiedza o społeczeństwie, IV etap, zakres rozszerzony, s. 160);

- charakteryzuje wybrane grupy społeczne ( $w$ tym rodzinę i grupy rówieśnicze), zawodowe, style życia (wiedza o społeczeństwie, III etap, s. 150; historia i społeczeństwo, II etap, s. 39);

- charakteryzuje wybrane problemy życia społecznego w Polsce (...), przemiany obyczajowe $\mathrm{w}$ świecie zachodnim $\mathrm{w}$ XX w. (przedmiot uzupełniający historia i społeczeństwo, blok tematyczny 3, IV etap, s. 291).

Jednak to, czy tematy te zostaną wykorzystane jako konteksty do refleksji na temat systemu ról rodzajowych i jego przemian, zależy od poszczególnych nauczycieli/-ek realizujących program.

Z kolei, przy wielu innych okazjach, gdzie można by uwzględnić perspektywę płci i rodzaju, w podstawach programowych można znaleźć odniesienie jedynie do innych obszarów dyskryminacji bądź przyczyn zmian, np.:

- ograniczanie wyjaśnień przemian w demografii do poziomu rozwoju gospodarczego, czynników przyrodniczych lub cywilizacyjnych (geografia, IV etap, zakres rozszerzony, s. 187, 182);

- wiązanie zróżnicowania i zmian w strukturze zatrudnienia jedynie z rozwojem nowych technologii/cywilizacji/państwa (geografia, IV etap, zakres podstawowy, s. 181; rozszerzony, s. 186);

- wskazywanie grup (ze względu na zróżnicowanie narodowe, etniczne, religijne, kulturowe, statusu materialnego; imigranci, uchodźcy) lub przyczyn (ksenofobia, antysemityzm, rasizm, szowinizm, terroryzm) rzeczywistej/potencjalnej nierówności lub dyskryminacji z pominięciem perspekty- 
wy rodzaju (edukacja społeczna, I etap, s. 14; etyka, I etap, s. 17; wiedza o społeczeństwie: III etap, s. 154; IV etap, zakres podstawowy, s. 159; rozszerzony, s. 161, 169);

- bardzo ogólne określanie kontekstu kształtowania własnej tożsamości jako różnorodności postaw społecznych, obyczajowych, narodowych, religijnych, etycznych, kulturowych, bez odnoszenia ich do płci/rodzaju (język polski, III etap, s. 80).

W świetle powyższej analizy można stwierdzić, że w podstawach programowych, wbrew deklaracji, że Szkoła podejmuje odpowiednie kroki w celu zapobiegania wszelkiej dyskryminacji (I i II etap, s. 10; III i IV etap, s. 75), raczej nie ma miejsca na krytyczną refleksję związaną z nierównościami płci, uwarunkowanymi pryzmatami rodzaju (polaryzacją płciową, esencjalizmem biologicznym i androcentryzmem ${ }^{9}$ ). Wrażenie to wzmacniają treści podkreślające przywiązanie do rodzimych tradycji, przy jednoczesnym poszanowaniu innych kultur i tradycji (np. edukacja społeczna, I etap, s. 14; język polski II etap, s. 63; historia i społeczeństwo II etap, s. 38; wychowanie do życia w rodzinie II etap, s. 57; III i IV etap, s. 75), a więc także tych, w których podporządkowanie i dyskryminacja kobiet jest powszechną praktyką społeczną. Prezentowanie rzeczywistości w sposób statyczny i wolny od konfliktów odbiera uczniom i uczennicom szansę doskonalenia kompetencji krytycznych, zaś samą edukację odziera z jej potencjału emancypacyjnego, zwłaszcza że można spotkać również zachęty do uznania obecnego porządku społecznego za naturalny i oczywisty. Na przykład, poprzez takie wymagania czy treści programowe:

- Ukazywanie sensu praw i obowiazków, zasad i regut, nakazów i zakazów obowiązujących $w$ różnych sytuacjach społecznych: w grupie rówieśniczej, w szkole, $w$ rodzinie, w społeczności lokalnej (etyka, II etap, s. 67);

- Rozpoznawanie swoich obowiązów wobec najbliższego otoczenia, rodziny i szkoty (etyka, II etap, s. 58);

- Przestrzega reguł obowiazujących w społeczności dziecięcej oraz świecie dorostych (edukacja społeczna, I etap, s. 14);

- Rozpoznaje role spoteczne, w których występuje oraz związane z nimi oczekiwania (wiedza o społeczeństwie, III etap, s. 150);

- Charakteryzuje swoje role społeczne i typowe dla nich zachowania (podstawy przedsiębiorczości, IV etap, s. 172).

Warto się zatem w tym kontekście zastanowić, w jaki sposób ma być realizowany cel: Kształtowanie u uczniów postaw warunkujacych sprawne $i$ odpowiedzialne funkcjonowanie we wspótczesnym świecie (III i IV etap, s. 73). Czy

${ }^{9} \mathrm{~S}$. Bem, Męskość, kobiecość. 
szkoła przygotuje kobiety i mężczyzn do wyzwań zmieniającego się świata i konieczności ciągłego renegocjowania społecznego „kontraktu płci”? Obecna $\mathrm{w}$ podstawach programowych, mniej lub bardziej świadoma, neutralność rodzajowa może wzmacniać praktykę i oddziaływanie różnych rodzajów seksizmu w rzeczywistości szkolnej, tworząc ukryty program kształtowania ról rodzajowych.

\section{Zakończenie}

Użytecznym sposobem rekonstrukcji filozofii edukacji na podstawie analizowanych dokumentów (Ustawa o systemie oświaty i podstawy programowe kształcenia ogólnego) jest odwołanie się do społecznych funkcji edukacji - funkcji rekonstrukcyjnej, adaptacyjnej i emancypacyjnej. Funkcje te rzadko bywają realizowane w jednakowym stopniu, co stanowi podstawę do zidentyfikowania preferencji konstruktorów programów i orzekania, czy programy skupiają się na przeszłości (w naszym przypadku np. transmisji tradycyjnego, patriarchalnego porządku płci), teraźniejszości (np. poprzez rzetelne opisywanie konfliktów i kryzysów towarzyszących dokonującej się na naszych oczach redefinicji ról i relacji rodzajowych), czy też na przyszłości (czego wskaźnikiem może być np. promowanie rozwiązań społecznych służących równości i sprawiedliwości rodzajowej). Ustaleniu filozofii edukacji służy przede wszystkim analiza celów i treści obecnych w podstawach programowych, która $\mathrm{w}$ jakiejś mierze pozwala oszacować rozwojowy i emancypacyjny potencjał programów szkolnych jako narzędzia zmiany społecznej. Z trzech funkcji edukacji dominujące okazują się funkcja rekonstrukcyjna i adaptacyjna i to mimo stwierdzenia braku powoływania się w bezpośredni sposób na stereotypy i uprzedzenia. Obraz świata, jaki wyłania się z podstaw programowych jest statyczny i wolny od konfliktów. Treści nauczania nie problematyzują rzeczywistości, nie zachęcają do jej krytycznej analizy i zmiany; służą głównie reprodukcji status quo w zakresie relacji rodzajowych. $W$ analizowanym materiale badawczym nie znaleziono ewidentnych wskaźników troski o emancypacyjną funkcję edukacji. Treści kształcenia nie wzbudzają dysonansu poznawczego, nie konfrontują uczniów i uczennic z wyzwaniami współczesnego świata, z dokonującymi się na ich oczach zmianami form życia społecznego, stwarzając tym samym mało okazji do doskonalenia kompetencji krytyczno-kreatywnych.

Do podobnych wniosków można też dojść posługując się pojemną kategorią analityczną edukacji ślepej versus neutralnej versus wrażliwej na płeć. Oba 
analizowane dokumenty pomijają całkowitym milczeniem kwestię płci/rodzaju. Kategoria ta jest nieobecna jako kryterium konstruowania treści i efektów kształcenia. Co więcej, stosowanie androcentrycznego języka (faworyzowanie uczniów, nauczycieli, a pomijanie jako adresatek - uczennic i nauczycielek) oraz zaniechanie jakichkolwiek działań promujących równość rodzajową skłania do podejrzeń, że autorzy i autorki podstaw programowych cechuje swoista ślepota rodzajowa. Można zaryzykować twierdzenie, że brakuje polityki gender mainstreaming w edukacji, a na straży realizacji ustawowych zapisów antydyskryminacyjnych stoją organizacje pozarządowe, a nie Ministerstwo Edukacji Narodowej. Edukacja zatem, wbrew oczekiwaniom, nadal przyczynia się do reprodukowania nierówności rodzajowych i pozbawia dyskryminowane grupy społeczne narzędzi walki o emancypację i upełnomocnienie. Ślepa, a w najlepszym razie neutralna rodzajowo edukacja pozbawia się potencjału emancypacyjnego, a uczniów i uczennice pozostawia bez kompetencji krytycznych, potrzebnych do zmiany świata na lepiej urządzony i bardziej sprawiedliwy.

\section{BIBLIOGRAFIA}

Bem S., Męskość, kobiecość. O różnicach wynikających z płci, Gdańskie Wydawnictwo Psychologiczne, Gdańsk 2000.

Konarzewski K., Reforma oświaty. Podstawa programowa i warunki ksztatcenia, Instytut Spraw Publicznych, Warszawa 2004.

Leach F., Practising Gender Analysis in Education, Oxfam GB, Oxford 2003.

Pankowska D., Wychowanie a role płciowe, Gdańskie Wydawnictwo Psychologiczne, Gdańsk 2005.

Rubacha K., Metodologia badań nad edukacja, Wydawnictwa Akademickie i Profesjonalne, Warszawa 2008. 